\title{
Influence of Integrated Nutrient Management (INM) on yield attributes and economics of kharif onion (Allium cepa L.) under loamy sand soils
}

\author{
S.K. Sharma ${ }^{1}$, O.P. Garhwal ${ }^{1}$, P. Mahala ${ }^{2}$ and T.V. Yadav ${ }^{3}$ \\ ${ }^{1}$ SKN College of Agriculture, Jobner, India \\ ${ }^{2}$ Regional Research Station (PAU), Ballowal Saunkhri, India \\ ${ }^{3}$ Curtin University, Perth, W. Australia
}

*Corresponding author

\section{A B S T R A C T}

\section{Keywords}

Kharif onion, INM,

Bio-fertilizers,

Vermicompost,

Inorganic fertilizers,

Yield

Article Info

Accepted:

20 May 2018

Available Online:

10 June 2018
A field experiment was conducted at Horticulture farm, S.K.N. College of Agriculture, Jobner (Rajasthan) during kharif, 2013 with sixteen treatment combinations including four levels of organic manures (Control; FYM @ 10 t ha-1; FYM @ 5 t ha-1 + vermicompost @ 2.5 t ha-1; FYM @ 5 t ha-1 + vermicompost @ 2.5 t ha-1+ bio-fertilizers) and four levels of inorganic fertilizers (Control, 100\% R D of NPK, NPK $+\mathrm{S}, \mathrm{NPK}+\mathrm{S}+\mathrm{Zn}$ ) in Randomized Block Design with three replications. The results indicated that combined application of FYM @ 5 t ha-1 + vermicompost @ 2.5 tha-1 + Bio-fertilizers, among the different treatments of organic manures proved significantly superior over rest of the treatments in respect to yield attributes viz., neck thickness $(1.069 \mathrm{~cm})$, diameter of bulb $(4.22 \mathrm{~cm})$, average weight $(98.80 \mathrm{~g})$, bulb yield $\left(15.81 \mathrm{~kg} \mathrm{plot}^{-1}\right)$, total bulb yield $(219.56 \mathrm{q}$ $\mathrm{ha}^{-1}$ ) ; net return (Rs. 2,01,705/- $\mathrm{ha}^{-1}$ ) and B:C ratio (3.26:1). Similarly yield attributes viz., neck thickness $(1.056 \mathrm{~cm})$, diameter of bulb $(4.29 \mathrm{~cm})$, average weight $(96.14 \mathrm{~g})$, bulb yield (15.38 kg plot ${ }^{-1}$ ), total bulb yield (213.64 q ha $\left.{ }^{-1}\right)$; net return (Rs $\left.195489 \mathrm{ha}^{-1}\right), \mathrm{B}$ : C ratio (3.21: 1) in onion bulb were significantly high in treatment of NPK,S \& Zn @ 100:50:100:20 \& $10 \mathrm{~kg} \mathrm{ha}^{-1}$.

\section{Introduction}

Onion (Allium cepa L.) is a bulbous biennial herb of family Alliaceae. It is commonly called as "Queen of kitchen" for its unique usage throughout the year in the form of salads, condiments or for cooking with other vegetables. The pungency in onion is due to sulphur compound "ally propyl disulphide" in the volatile oil and the outer skin colour is due to the presence of "querctin" (Nadkarni, 1954). Onion bulb is rich in minerals like phosphorus $(50 \mathrm{mg} / 100 \mathrm{~g})$, iron $(0.7 \mathrm{mg} / 100 \mathrm{~g})$, calcium $\quad(18 \mathrm{mg} / 100 \mathrm{~g}), \quad$ carbohydrates $(11.0 \mathrm{~g} / 100 \mathrm{~g})$, protein $(1.2 \mathrm{~g} / 100 \mathrm{~g})$, vitamins 'C' $(11 \mathrm{mg} / 100 \mathrm{~g})$, fibers $(0.6 \mathrm{~g} / 100 \mathrm{~g})$ and nicotinic acid $(0.4 \mathrm{mg} / 100 \mathrm{~g})$ (Aykroyd, 1963).

There is ample necessity to standardise Integrated Nutrient Management (INM) for increasing production and productivity in light textured soil. Production of onion in kharif season is necessary to have continuous supply of onion round the year. Organic manures 
stimulates the production of polysaccharides and other compounds that favours aggregation of fine soil particles, thereby promoting good structure, improved tilth, aeration, moisture movement and retention (Bose et al., 2001). Bio-fertiliser inoculation like Azosprillium, PSB helps the plants to attain better vegetative growth and increases yield by 10-30 percent (Mohondas, 1999. The present investigation was taken up to study effect of organic manures, inorganic manures and bio-fertilisers on kharif onion in loamy sand soil.

\section{Materials and Methods}

The experiment was conducted during 2013 at Horticulture farm, S.K.N. College of Agriculture, Jobner (Jaipur) during rabi season. The soil of experimental field was

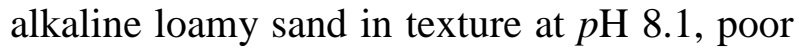
in organic carbon $(0.135 \%)$, available $\mathrm{N}$ (134.70 kg/ha), P (16.85 kg/ha), K (151.65 $\mathrm{kg} / \mathrm{ha})$ and $\mathrm{Zn}(0.42 \mathrm{mg} / \mathrm{kg}$ soil $)$. The experiment was laid with sixteen treatment combinations including four levels of organic manures (Control; FYM @ 10 t ha ${ }^{-1}$; FYM @ $5 \mathrm{tha}^{-1}+$ vermicompost@2.5 tha ${ }^{-1}$; FYM @ $5 \mathrm{t} \mathrm{ha}^{-1}+$ vermicompost @ $2.5 \mathrm{t} \mathrm{ha}^{-1}+$ biofertilizers) and four levels of inorganic fertilizers (Control, 100\% R D of NPK, NPK $+\mathrm{S}, \mathrm{NPK}+\mathrm{S}+\mathrm{Zn}$ ) in Randomized Block Design with three replications. Randomization of the treatments was done with the help of random number table as advocated by Fisher (1950). The plot size was $2.4 \mathrm{~m} \mathrm{X} 3.0 \mathrm{~m}$ with $30 \mathrm{~cm} \times 15 \mathrm{~cm}$ spacing between rows and plants. Farm Yard manure (FYM) and Vermicompost were spread in the beds uniformly before transplanting of seedling. Azosprillium and Phosphorus Solubulizing Bacteria (PSB) were applied as $100 \mathrm{~g}$ per acre culture dissolved of water and dipping the bulb of the onion in solution for 10-20 minutes before sowing and dried in shade (Paul et al., 1971). Yield attributes were calculated using standard methods. For calculating economics, the average treatment yield along with prevailing market rates for inputs and output are used. The net return was calculated by subtracting the cost of cultivation for each treatment. The 'F-test' and critical difference (CD) calculated to test significance of difference among the treatments, wherever the results were significant.

\section{Results and Discussion}

\section{Effect of organic manures on yield and yield attributes}

The significant increase in yield and yield attributes was observed with application of of FYM @ $5 \mathrm{t} \mathrm{ha}^{-1}+$ Vermicompost @ $2.5 \mathrm{t} \mathrm{ha}^{1}$ + Bio-fertilizers (Azosprillium + PSB) over the control. The increase in yield and yield attributes with application of FYM + Vermicompost + Bio-fertilizers may be ascribed due to sustained availability of balanced nutrient throughout the growing period and which resulted increased vegetative growth (Warade et al., 1996).

\section{Effect of inorganic fertilisers on yield and yield attributes}

The significantly enhanced neck thickness, diameter of bulb, average weight of bulb and bulb yield per plot and total bulb yield $\mathrm{ha}^{-1}$ were observed with the increasing level of inorganic fertilizers. The application of NPK $\left(100: 50: 100 \mathrm{~kg} \mathrm{ha}^{-1}\right)+\mathrm{S}+\mathrm{Zn}$ gave significantly maximum increase in yield and yield attributes of onion crop over control. The application of inorganic fertilizers alone might supply one or two nutrients only but combined application of macro and micro nutrient fertilizers the responses of the micronutrients viz. Mo, $\mathrm{Fe}$ and Zinc have also been found in promising to increase the productivity of the soil (Masood Ali and Mishra 2000), Gupta et al. 2012 and Chavan et al. 2012. The direct addition of multi nutrients might have also increased the availability of these nutrients, which in turned increased enter of nutrients. 
Table.1 Effect of Integrated Nutrient Management (INM) on yield attributes and economics of kharif onion (Allium cepa L.) under loamy sand soils

\begin{tabular}{|c|c|c|c|c|c|c|c|}
\hline Treatments & $\begin{array}{c}\text { Neck } \\
\text { thickness of } \\
\text { bulb }(\mathrm{cm})\end{array}$ & $\begin{array}{l}\text { Diameter of } \\
\text { bulb }(\mathrm{cm})\end{array}$ & $\begin{array}{l}\text { Average } \\
\text { Weight of } \\
\text { bulb (g) }\end{array}$ & $\begin{array}{c}\text { Bulb yield } \\
\text { (kg/plot) }\end{array}$ & $\begin{array}{l}\text { Total bulb } \\
\text { yield (q/ha) }\end{array}$ & $\begin{array}{c}\text { Net Returns } \\
\text { (Rs.) }\end{array}$ & B:C Ratio \\
\hline \multicolumn{8}{|l|}{ Organic manures } \\
\hline Control $\left(\mathbf{M}_{\mathbf{0}}\right)$ & 0.974 & 3.00 & 76.45 & 12.23 & 169.89 & 148334 & 2.66 \\
\hline FYM 10 t ha $^{-1}\left(\mathbf{M}_{1}\right)$ & 1.028 & 3.99 & 87.40 & 13.98 & 194.23 & 175549 & 3.04 \\
\hline FYM $5 \mathrm{t} \mathrm{ha}^{-1}+$ V.C. $2.5 \mathrm{t} \mathrm{ha}^{-1}\left(\mathbf{M}_{2}\right)$ & 1.061 & 4.05 & 93.98 & 15.04 & 208.84 & 189078 & 3.07 \\
\hline $\begin{array}{l}\text { FYM } 5 \mathrm{t} \mathrm{ha}^{-1}+\text { V.C. } 2.5 \mathrm{t} \mathrm{ha}^{-1}+\text { Bio- }^{-} \\
\text {fertilizers (Azosprillium+PSB) }\left(\mathbf{M}_{3}\right)\end{array}$ & 1.069 & 4.22 & 98.80 & 15.81 & 219.56 & 201705 & 3.26 \\
\hline SEm \pm & 0.003 & 0.05 & 0.40 & 0.06 & 0.90 & 1076 & 0.02 \\
\hline $\mathrm{CD}(\mathrm{p}=\mathbf{0 . 0 5})$ & 0.010 & 0.14 & 1.16 & 0.19 & 2.58 & 3098 & 0.05 \\
\hline \multicolumn{8}{|l|}{ Inorganic fertilisers } \\
\hline Control $\left(\mathbf{F}_{\mathbf{0}}\right)$ & 0.994 & 3.20 & 77.20 & 12.35 & 171.55 & 150048 & 2.67 \\
\hline $\operatorname{NPK}\left(\mathbf{F}_{1}\right)$ & 1.032 & 3.76 & 89.11 & 14.26 & 198.02 & 177835 & 2.96 \\
\hline $\mathrm{NPK}+\mathrm{S}\left(\mathbf{F}_{\mathbf{2}}\right)$ & 1.051 & 4.02 & 94.19 & 15.07 & 209.31 & 191293 & 3.19 \\
\hline $\mathrm{NPK}+\mathrm{S}+\mathrm{Zn}\left(\mathbf{F}_{\mathbf{3}}\right)$ & 1.056 & 4.29 & 96.14 & 15.38 & 213.64 & 195489 & 3.21 \\
\hline SEm \pm & 0.003 & 0.05 & 0.40 & 0.06 & 0.90 & 1076 & 0.02 \\
\hline$C D(p=0.05)$ & 0.010 & 0.13 & 1.16 & 0.19 & 2.58 & 3098 & 0.05 \\
\hline
\end{tabular}

V.C. $=$ Vermi-compost, FYM. $=$ Farm Yard Manure 
Table.2 Interaction effect of Organic and Inorganic fertilisers on yield attributes of kharif onion (Allium cepa L.) under loamy sand soils

\begin{tabular}{|c|c|c|c|c|c|c|c|c|c|c|c|c|}
\hline \multirow{2}{*}{$\begin{array}{l}\text { Organic } \\
\text { Inorganic }\end{array}$} & \multicolumn{4}{|c|}{ Avg. weight of onion bulb (g) } & \multicolumn{4}{|c|}{ Bulb yield (kg/plot) } & \multicolumn{4}{|c|}{ Total bulb yield (q/ha) } \\
\hline & $\mathbf{M}_{\mathbf{0}}$ & $\mathbf{M}_{1}$ & $\mathbf{M}_{2}$ & $\mathbf{M}_{3}$ & $\mathbf{M}_{\mathbf{0}}$ & $\mathbf{M}_{1}$ & $\mathbf{M}_{2}$ & $\mathbf{M}_{3}$ & $\mathbf{M}_{\mathbf{0}}$ & $\mathbf{M}_{1}$ & $\mathbf{M}_{2}$ & $\mathbf{M}_{3}$ \\
\hline $\mathbf{F}_{\mathbf{0}}$ & 60.78 & 75.42 & 84.46 & 88.13 & 9.72 & 12.07 & 13.51 & 14.10 & 135.06 & 167.60 & 187.68 & 195.85 \\
\hline $\mathbf{F}_{1}$ & 72.34 & 85.70 & 97.09 & 101.32 & 11.57 & 13.71 & 15.53 & 16.21 & 160.76 & 190.44 & 215.75 & 225.15 \\
\hline $\mathbf{F}_{2}$ & 80.07 & 94.89 & 99.61 & 102.17 & 12.81 & 15.18 & 15.94 & 16.35 & 177.94 & 210.87 & 221.36 & 227.05 \\
\hline $\mathbf{F}_{3}$ & 92.60 & 93.61 & 94.75 & 103.59 & 14.82 & 14.98 & 15.16 & 16.57 & 205.78 & 208.01 & 210.56 & 230.19 \\
\hline SEM \pm & 1.61 & & & & 0.26 & & & & 3.59 & & & \\
\hline$C D(p=0.05)$ & 4.62 & & & & 0.74 & & & & 10.33 & & & \\
\hline
\end{tabular}

Table.3 Interaction effect of Organic and Inorganic fertilisers on economics of kharif onion (Allium cepa L.) under loamy sand soils

\begin{tabular}{|c|c|c|c|c|c|c|c|c|c|c|}
\hline \multirow{2}{*}{\multicolumn{2}{|c|}{ Organic }} & \multicolumn{4}{|c|}{ Net Returns (Rs.) } & \multicolumn{5}{|c|}{ Benefit : Cost Ratio } \\
\hline & & $\mathbf{M}_{\mathbf{0}}$ & $\mathbf{M}_{1}$ & $\mathbf{M}_{2}$ & $\mathbf{M}_{3}$ & $\mathbf{M}_{\mathbf{0}}$ & & $\mathbf{M}_{1}$ & $\mathbf{M}_{2}$ & $\mathbf{M}_{3}$ \\
\hline $\mathbf{F}_{\mathbf{0}}$ & & 109821 & 146870 & 166968 & 176532 & 2.10 & & 2.71 & 2.87 & 3.02 \\
\hline $\mathbf{F}_{1}$ & & 136682 & 170290 & 196664 & 207704 & 2.43 & & 2.92 & 3.16 & 3.32 \\
\hline $\mathbf{F}_{2}$ & & 157214 & 194732 & 203321 & 209907 & 2.79 & & 3.34 & 3.26 & 3.36 \\
\hline $\mathbf{F}_{3}$ & & 189618 & 190303 & 189361 & 212667 & 3.31 & & 3.21 & 2.99 & 3.35 \\
\hline SEM \pm & & 4304 & & & & 0.07 & & & & \\
\hline $\mathrm{CD}(\mathrm{p}=0.05)$ & & 12393 & & & & 0.21 & & & & \\
\hline $\mathbf{F}_{\mathbf{0}}$ & - & Control & & & & & - & Control & & \\
\hline $\mathbf{F}_{1}$ & - & NPK & & & & & - & FYM $10 \mathrm{t} \mathrm{ha}^{-1}$ & & \\
\hline $\mathbf{F}_{2}$ & - & $\mathrm{NPK}+\mathrm{S}$ & & & & & - & FYM $5 \mathrm{t} \mathrm{ha}^{-1}$ & $5 \mathrm{t} \mathrm{ha}^{-1}$ & \\
\hline $\mathbf{F}_{3}$ & - & $\mathrm{NPK}+\mathrm{S}+\mathrm{Zn}$ & & & & & - & $\begin{array}{l}\text { FYM } 5 \mathrm{t} \mathrm{ha}^{-1} \\
\text { (Azosprillium }\end{array}$ & $5 \mathrm{t} \mathrm{ha}^{-1}+$ & lizers \\
\hline
\end{tabular}




\section{Interactive effect of organic and inorganic} fertilisers

The interactive effect of treatments showed that increase in organic manures at the same level of inorganic fertilizers resulted in maximum average weight of bulb, bulb yield per plot and total bulb yield ha ${ }^{-1}$, net return, B: C ratio under treatment combination FYM @ $5 \mathrm{t} \mathrm{ha}^{-1}+$ Vermicompost @ $2.5 \mathrm{t} \mathrm{ha}^{1}+$ Bio-fertilizers (Azosprillium + PSB) and NPK $\left(100: 50: 100 \mathrm{~kg} \mathrm{ha}^{-1}\right)+\mathrm{S}+\mathrm{Zn}$ (Table 2 and $3)$.

Application of organic manures in the form of FYM and vermicompost increased the average weight of bulb and bulb yield per plot, total bulb yield ha ${ }^{-1}$, net return, B: C ratio.

The beneficial response of FYM and vermicompost to yield might also be attributed to the availability of sufficient amount of plant nutrients in balanced way in inorganic form throughout the growth period and especially at critical growth period of crop resulting in better uptake, plant vigour and superior yield attributes (Rao and Sitaramayya, 2000).

\section{Economics}

The highest net return (Rs 201705Rs ha- ${ }^{1}$ ) and $\mathrm{B}$ : $\mathrm{C}$ ratio (3.26) from the onion crop were obtained at $\mathrm{M}_{3}\left(5 \mathrm{t} \mathrm{ha}^{-}{ }^{1} \mathrm{FYM}+2.5 \mathrm{t}\right.$ ha${ }^{1}$ Vermicompost + biofertilizers (Azosprillium $+\mathrm{PSB}$ ) with NPK+S+Zn and followed by $5 \mathrm{t}$ $\mathrm{ha}^{-1} \mathrm{FYM}+2.5 \mathrm{t} \mathrm{ha}^{-1}$ Vermi-compost) with $\mathrm{NPK}+\mathrm{S}$, net return (Rs $195489 \mathrm{ha}^{-1}$ ) and B:C ratio (3.21) showed in the table 1.

This clearly brings out the people to use biofertilizers for getting better returns.

The interaction effect of organic manures and inorganic fertilizers were found significant.

\section{References}

Aykrody WR. 1963. ICMR. Special Report, Series, No. 42.

Bose TK, Kabir j, Das P and Joy RP. 2001. Organic farming in horticulture crops. Tropical Horticulture, 2:20, Publishing Naya Prakash,New Delhi, p.150.

Chavan AS, Khafi HR, Raj AD, Parmar RM, Shekh MA. 2012. Effect of potassium and zinc on growth and yield of cowpea (Vigna unguiculata L. Walp.). Research on crops, 6 (2):432-34.

Fisher RA. 1950. Statistical method for research workers, Oliver and Boyd, Edinburg, London.

Gupta SC and Ganagular S. 2012. Effect of molybdenum iron and mineral inoculation on symbiotic strain, nutrient uptake and yield of chickpea. Journal of food legume. 25:45-49.

Masood Ali and Mishra JP. 2000. Nutrient management in pulses and pulses based cropping system. Fertilizer news. 45(4):59-69.

Mohandas S.1999. Biofertilizer for Horticulture crops. Indian Horticulture. 43 (4):32-37.

Nadkarni KN.1954. Allium cepa Linn and Allium sativum Linn. Indian Materia Medica, Popular book depot, Bombay : 963.

Paul NB, Rewari RB, Sen A, Sundeao WVB and Bhatnagar RS. 1971. Rhizobial inoculation of pulse crops for better yield. Division of microbiology, New vistas in pulse production, IARI, New Delhi, pp-47-56.

Rao SS and Sitaramnayya M. 2000. Performance of alternate organic nitrogen sources in a inceptisol under Rice. International Conference Managing Natural Resources for sustainable Agriculture production in the $21^{\text {th }}$ century, New Delhi, 3: 1464465. 
Warade SD, Dasale SB and Shinde KG. 1996. Effect of organic inorganic and bio fertilizer on yield of onion bulb cv. B-
780. Journal of Maharashtra Agriculture University 20: 467-68.

\section{How to cite this article:}

Ankita and Gandge, R.S. 2018. Prevalence and Antibiotic Susceptibility Pattern of Staphylococcus Species in Canine Skin Infection. Int.J.Curr.Microbiol.App.Sci. 7(06): 2806-2811. doi: https://doi.org/10.20546/ijcmas.2018.706.328 